\title{
Demokrasi Lokal
}

Shohibul Anshor Siregar

Telah luas diberitakan bahwa Presiden Jokowi sangat menaruh dukungan penuh kepada Menteri Dalam Negeri, sesuai dengan kewenangannya, yang telah membatalkan 3.143 peraturan daerah yang bermasalah. Sebetulnya ini bukan kali pertama dalam sejarah otonomi Indonesia.

Dalam hal keterkaitannya dengan potensi penghambatan terhadap dinamika pembangunan nasional, regulasi yang dinilai buruk dan menghambat itu juga bukan sesuatu yang menjadi persoalan daerah ansich. Kementerian Bappenas misalnya menyebut ada sekitar 42.000 aturan yang bermasalah dalam bentuk perpres, PP, permen, hingga perda. Jadi, ini sebetulnya seperti menepuk air di dulang saja.

Ketika muncul reaksi atas dugaan bahwa di antara 3.143 Perda yang dibatalkannya banyak peraturan daerah yang dalam politik Indonesia lebih dikenal dengan peraturan daerah berbasis Syariah Islam (Perda Syari'ah), Menteri Dalam Negeri Tjahjo Kumolo membantah. Padahal telah luas juga diketahui bahwa Tjahjo Kumolo tidak memberi tahu siapa-siapa daftar perda-perda yang dibatalkannya itu, meski ketika dipertanyakan tentang perda syari'ah ia menjawab tidak. Karena itulah banyak pihak termasuk Wapres JK meminta segera diumumkan. Jika hingga kini pengumumannya belum dilakukan, berarti ada masalh yang sangat serius di situ.

Dalam hal penyebutan sebetulnya apa yang dimaksudkan sebagai Perda Syari'ah di Indonesia tidak benar. Menurut mantan Ketua Mahkamah Konstitusi Hamdan Zoleva, yang mengaku sudah mengkaji Perda-perda itu, hampir seluruhnya tidak ada Perda Syari'ah. Karena yang ada sebetulnya hanyalah Perda mengenai ketertiban umum seperti larangan perizinan minum minuman keras, dan secara formal tak menyebut Perda Syari'ah. Apa yang selama ini dikhawatirkan oleh pihak-pihak tertentu ialah semangat diskriminasi dan intoleransi. Hamdan Zoelva menilai Perda-perda tersebut, seperti peraturan baca tulis al-Qur'an akan menjadi diskriminatif apabila diterapkan di wilayah yang tidak tepat.

Formalisasi. Perda Syari'ah itu adalah sesuatu yang dapat disebut sebagai sebuah formalisasi belaka, dan ke depan pasti akan bertambah lagi dengan dimensi-dimensi pengaturan yang lebih spesifik. Disebut formalisasi adalah karena fakta bahwa hal itu merupakan living reality dalam kelembagaan kehidupan social masyarakat sehari-hari bahkan sejak dahulu. Karena itu, jika ada penentangan terhadapnya tentulah disebabkan oleh berbagai faktor yang terkait dengan hal-hal bersifat subjektif berdasarkan faham dan agenda-agenda keagamaan yang dinilai bertlawanan arah dalam rivalitas yang tak kunjung usai. Terkadang malah lucu, perda Syari'ah dimusuhi, padahal hampir semua Bank membanggakan program syari'ah mereka yang bahkan dianggap sebuah keunggulan pula.

Jika ditelusuri ke belakang, sebetulnya formalisasi pemberlakukan syari'at Islam di Indonesia memiliki akar sejarah dan juridis yang sangat kuat. Pasal 29 ayat (2) UUD 1945 adalah jaminan untuk itu. Itu jugalah yang dikemukakan oleh Jurubicara FPI Munarman usai memimpin rombongan mendatangi kantor Harian Kompas di Jakarta, 
pekan lalu. Tidak perlu ada keraguan bahwa sebetulnya kebijakan otonomi daerah di Indonesia adalah sebuah solusi politik yang berimplikasi pada keterbukaan peluang yang sangat lebar bagi daerah untuk memberlakukan corak hukumnya masing-masing. Pada situs wWW.scribd.com/doc/131377425/ mencatat adanya 151 Perda Syari'ah ditambah 1 perda (2007) berdasarkan Injil, yang secara spesifik menjelaskan mengenai pelarangan minuman beralkohol dan kegiatan prostitusi, peraturan mengenai busana dan persekutuan, termasuk pelarangan penggunaan dan pemakaian simbol-simbol agama, dan pelarangan pembangunan rumah-rumah ibadat agama lain didekat Gereja, di Papua Barat.

Berdasarkan sumber tersebut di atas, di Provinsi Aceh terdapat 6 Perda Sayari'ah. Provinsi Sumatera Utara (1), Provinsi Sumatra Barat (25), Provinsi Riau (3), Provinsi Sumatera Selatan (1), Provinsi Bangka Belitung (1), Provinsi Bengkulu (3), Provinsi Lampung (3), Provinsi Banten (6), Provinsi Jawa Barat (30), Provinsi Jawa Tengah (1), Provinsi DIY (1), Provinsi Jawa Timur (11), Provinsi Kalimantan Selatan (17), Provinsi Kalimantan Barat (1), Provinsi Kalimantan Tengah (1), Provinsi Sulawesi Selatan (22), Provinsi Gorontalo (2), Provinsi Sulawesi Utara (1), Provinsi NTB (11), Provinsi NTT (1). Perlu dicatat bahwa data update-nya lebih banyak lagi dari yang disebutkan di atas.

Menilik isinya, Muhammad Fadhly Ase, SHI dalam tulisan berjudul "Mengkaji ulang eksistensi perda bermuatan syari'ah: sebuah pendekatan yuridis normatif" menjelaskan bahwa jenis-jenis perda syari'at yang telah diproduk beberapa pemerintah daerah di Indonesia terdiri dari empat klasifikasi. Pertama, jenis yang terkait dengan isu moralitas masyarakat secara umum, anti pelacuran dan perzinaan. Kedua, jenis perda yang terkait dengan ketentuan/keharusan menutup aurat bagi muslimah. Ketiga, jenis perda yang terkait dengan keterampilan beragama seperti keharusan pandai baca-tulis Alquran. Keempat, jenis yang terkait mobilisasi dana umat seperti zakat, infaq, dan shadaqah.

Muhammad Fadhly Ase, SHI juga mengemukakan bahwa pada zaman kolonial Belanda dikenal adanya tiga teori hukum yang dapat membantu memahami pemberlakuan perda syari'ah di Indonesia. Ketiga teori itu ialah receptie incomplexu, receptie, dan receptie a contrario. Teori receptie in complexu yang kurang lebih dapat dimaknai menegaskan bahwa syari'at Islam secara keseluruhan berlaku bagi pemelukpemeluknya. Pada tahun 1882 Pemerintah Hindia Belanda pun mendirikan Peradilan Agama untuk mangakomodasi keptningan pemeluk Agama Islam. Kaitkan pulalah ini dengan bunyi sila pertama Pancasila yang termuat dalam Piagam Jakarta. Kita wajib mencatat bahwa melalui Peradilan Agama inilah pulalah untuk pertama kalinya hukum Islam diformalkan di Indonesia.

Berlawanan dengan itu van Vollenhoven dan Snouck Hurgronje mengajukan teori teori receptive yang memprasyaratkan bahwa jika hukum Islam akan diberlakukan, mestinyalah dengan pertimbangan bahwa pemberlakuan itu sepanjang tidak bertentangan dengan hukum adat. Akhisnya pada tahun 1937 pemerintah Hindia Belanda mengeluarkan staatsblad Nomor 116 yang mencabut wewenang Peradilan Agama di luarmasalah perkawinan dan perceraian. 
Sajuti Thalib mengajukan teori receptie a contrario yang jika dijejaki adalah merupakan pengembangan teori yang sebelumnya dikemukakan Hazairin. Intinya hukum yang berlaku bagi rakyat adalah hukum agamanya, yang dengan begitu maka hukum adat hanya akan dapat berlaku kalau tidak ditemukan bertentangan dengan hukum Islam.

Jika pada tahun 1974 terbit UU Nomor 1 Tentang perkawinan, maka hal itu jelas-jelas sebuah monumentasi fenomenal yang berakar pada teori receptie a contrario. Pada tahun 1989 UU nomor 73 tentang Peradilan Agama disahkan pula yang diikuti dengan dikeluarkannya Inpres Nomor 1 tahun 1991 tentang Kompilasi Hukum Islam. Pada tanggal 16 Juli 2008 disahkan Undang-Undang nomor 21 tahun 2008 tentang Perbankan Syari'ah. Berlakunya syari'at Islam tampaknya hanyalah sebuah keniscayaan belaka. Bukankah setiap muslim dituntut dan diwajibkan menjalankan hukum Islam secara kaffah (totally), baik itu hukum Jinayah, Siyasah, Al-Ahwal AlSyakhsiyah dan Muamalat.

Bertentangankah Perda Syari'ah dengan hukum nasional? UUD 1945 telah mengatur tentang pemerintahan daerah pada pasal 18 yang terdiri dari 3 pasal, yaitu pasal 18 terdiri dari 7 ayat, pasal 18 A terdiri dari 2 ayat, dan pasal 18 B juga terdiri atas 2 ayat. Dalam Pasal 18 ayat (5) Perubahan Kedua UUD 1945 dinyatakan: "Pemerintahan daerah menjalankan otonomi seluas-luasnya, kecuali urusan pemerintahan yang oleh undang-undang ditentukan sebagai urusan Pemerintah Pusat." Pada ayat (6) pasal yang sama dinyatakan pula bahwa "Pemerintahan daerah berhak menetapkan peraturan daerah dan peraturan-peraturan lain untuk melaksanakan otonomi dan tugas perbantuan”.

Konflik Berkepanjangan. Saya ingat pada pertengahan tahun 2006 sebanyak 56 Anggota DPR menentang adanya Peraturan Daerah berbasis Syari'ah (Perda Syari'ah). Bahkan mereka mengajukan memorandum kepada pimpinan DPR agar mendesak pemerintah membatalkan peraturan-peraturan daerah yang berdasarkan hukum agama Islam. Penandatangan memorandum itu berasal dari PDI Perjuangan, Partai Kebangkitan Bangsa dan Golkar.

Di pihak lain memorandum itu ditentang oleh anggota DPR lainnya dengan jumlah lebih besar, yakni 134 orang. Para penentang ini terdiri dari legislator Partai Keadilan Sejahtera dan PPP. Ketika itu salah seorang yang menjadi motor penggerak ke 134 legislator itu ialah Lukman Hakim dari PPP (kini ia menjabat Menteri Agama). Dengan alasan perda-perda tersebut memang sangat dibutuhkan untuk memerangi berbagai jenis aksi judi dan pelacuran dengan segenap anatomi budaya, ekonomi dan mafianya, ia meminta agar pimpinan DPR mengabaikan usulan kelompok penentang Perda Syari'ah. Anggapan yang menyebutkan Perda Syari'ah melanggar konstitusi mereka tampik.

Akhirnya melalui rapat konsultasi antara pimpinan DPR dan pimpinan seluruh fraksi di DPR ditemukan titik kompromi. Kontroversi dinganggap selesai. Mungkin karena para penandatangan memorandum sudah mengukur banyak resiko (kalah voting dan citra negatif di tengah masyarakat yang pasti akan dikategorikan sebagai anti Islam), surat memorandum yang berkeberatan dengan perda berbau syariat Islam tidak jadi dikirim 
ke Presiden. Waktu itu Patrialis Akbar dari Fraksi PAN mengatakan, bahwa masalah agama sangat sensitif. Apa perlunya dipersoalkan lagi, pada saat nilai-nilai agama itu sudah menjadi bagian dari hidup rakyat Indonesia.

Penutup. Demokrasi lokal di Indonesia masih memiliki agenda besar yang ibarat sebuah perjalanan baru dijejaki sekitar $1 \%$ saja. Ketakutan pemerintah terhadap otonomi yang di dalamnya termasuk soal urgensi pemberian keleluasaan untuk menatata kehidupan di daerah, sudah jelas-tegas kelihatan dalam konstruk regulasi yang dibuat dan revisi demi revisinya yang begitu gencar. Memang tak dapat disembunyikan bahwa pemerintah memang penuh rasa ketakutan terhadap otonami daerah. Akankah pencabutan demokrasi akan berlangsung ke depan? Entahlah Marilah kita tunggu saja.

Shohibul Anshor Siregar Naskah ini pertamakali diterbitkan oleh Harian Waspada Medan, Senin 20 Juni 2016, hlm B7 